\title{
The Philosopher as a Child of His Own Time
}

Rorty on Irony and Creativity

Javier Toro

\section{(2) OpenEdition \\ Journals}

Electronic version

URL: http://journals.openedition.org/ejpap/580

DOI: $10.4000 /$ ejpap.580

ISSN: 2036-4091

Publisher

Associazione Pragma

\section{Electronic reference}

Javier Toro, «The Philosopher as a Child of His Own Time », European Journal of Pragmatism and American Philosophy [Online], V-1 | 2013, Online since 16 July 2013, connection on 03 May 2019. URL: http://journals.openedition.org/ejpap/580 ; DOI : 10.4000/ejpap.580

This text was automatically generated on 3 May 2019.

\section{(c) (i)}

Author retains copyright and grants the European Journal of Pragmatism and American Philosophy right of first publication with the work simultaneously licensed under a Creative Commons AttributionNonCommercial-NoDerivatives 4.0 International License. 


\title{
The Philosopher as a Child of His Own Time
}

\author{
Rorty on Irony and Creativity
}

Javier Toro

The community stagnates without the impulse of the individual. The impulse dies away without the sympathy of the community.

William James, "Great Men, Great Thoughts, and the Environment," Atlantic Monthly, October, 1880.

\section{Introduction}

1 By the time Richard Rorty wrote Contingency, Irony, and Solidarity he was convinced that it was impossible to fulfill his adolescent yearning of holding "reality and justice in a single vision," fusing private enlightenment with public justice. This yearning is better represented in the Platonic tradition which holds that there is something necessary and transcendental about human nature and values, that solidarity is based on objectivity, not the other way around:

The attempt to fuse the public and the private lies behind both Plato's attempt to answer the question 'Why is it in one's interest to be just?' and Christianity's claim that perfect self-realization can be attained through service to others. Such metaphysical or theological attempts to unite a striving for perfection with a sense of community require us to acknowledge a common human nature. They ask us to believe that [...] the springs of private fulfillment and of human solidarity are the same. (Rorty 1989: xiii)

2 According to Rorty, such Platonic yearning is at the core of all our western philosophic tradition in the sense that it has been, in part, due to this yearning that the grand philosophical systems (such as the Cartesian and Kantian quests for certainty) have arisen. Such yearning is not to be ignored by the philosopher, since it seems to stand amidst all of philosophy's enterprises. 
3 As a reaction to this impulse, Rorty claims that it is not necessary to marry justice and reality, fuse the public and the private; in other words, it is not necessary to make coincide our moral responsibilities to others with our most private yearnings, regardless that such yearnings be entirely philosophical or simply aesthetical (like one's egotistical love to wild orchids, or Proust's novels). As he acknowledges in an autobiographical passage:

One should try to abjure the temptation to tie in one's moral responsibilities to other people with one's relation with whatever idiosyncratic things or persons one loves with all one's heart and soul and mind... The two will, for some people, coincide [...] but they need not co-incide, and one should not try too hard to make them do so (Rorty 1999: 13).

For Rorty, the most valuable philosophers and intellectuals - or at least those who provide us with tools to cope with our reality and whose vocabulary has eventually become the canon - are those historicists who acknowledge the contingency of their thought and vocabularies. The imaginative creativity of such philosophers is not very far from the creative drive of the poet; in fact, in different places Rorty sees the philosopher as constructing a poetic narrative. ${ }^{2}$ The best example of this sort of philosopher-as-poet is, Rorty tells us, Nietzsche, who

by treating Socrates as one more mythmaker rather than as someone who employed reason to break free of myth, he lets us see Parmenides and Plato as alltoo-strong poets. (Rorty 2007: 110)

Heidegger and Wittgenstein are also good examples of the type of ironist-historicist philosopher which Rorty had in mind, because these two authors were mainly concerned with self-creation and private perfection instead of justice and general well-being. Nietzsche, Proust, Heidegger, Wittgenstein, Derrida and Foucault, among many others, are grouped together by Rorty as the kind of intellectual who has criticized final vocabularies and has created its own vocabulary, but all in account of private selffulfillment. On the other hand, other historicist authors such as Marx, Dewey, and Habermas, who also created their own vocabulary, saw such self-concern as a selfish intellectual exercise which needed to be abandoned for the search of social welfare and public justice.

6 Rorty - especially in his book Contingency, Irony, and Solidarity - doesn't try to synthesize both groups of historicist writers; rather, he insists on giving up such efforts and live happily with the split result. Such outcome is a toolbox which helps us cope with different and limited aspects of our reality, not all of it. Thus, Nabokov's novels and Wittgenstein's philosophy help us cope with certain aspects of our reality, in dealing with certain limited problems. At the same time, Habermas' and Dewey's books come handy in some cases (namely, when it comes to understand the struggles of societies' quest for certainty throughout history), but completely irrelevant when it comes to give us inspiration for our private self-creation.

7 The moral behind Rorty's ironic philosophy is that our lives make much more sense when we drop the Platonic yearning for metaphysical unity of reality. The outcome is, though, that our sense of moral responsibility might not have a transcendental and rational basis, but it is there nevertheless, since it is what comes naturally for us to do.

In what follows, I will argue against such detached view of philosophical creativity. First, I will argue that Rorty's ironist contradicts the image of the pragmatist philosopher which Rorty himself shared with the classical pragmatists. Then, I will point that Rorty's 
insistence on the dichotomy between the public and the private is exaggerated and fails to acknowledge the deep entanglement between the two. However, in this essay I want to rescue what is valuable from Rorty's philosophy and read between the lines, trying to form a general view of his philosophy, rather than focusing on some unfortunate lines of his; thus, in some sense, I will try to save Rorty from himself. This way of reading Rorty is not that far from John Horton's way of interpreting the American philosopher, since he suggests an approach which

involves treating Rorty in a more receptive spirit, one which involves the benefit of the doub and which genuinely seeks to understand what it is that he is trying to say and why. It means treating Rorty in the spirit in which he often treats otherstaking up what is useful, pursuing what looks promising and rejecting or passing over what looks to be his less impressive lines of thought. (Horton 2001: 16)

This approach, though, as Horton also points out, does not imply giving up on critical rigor and analysis and does not mean giving up an effort to find internal difficulties in Rorty's writings. However, it means to treat the American pragmatist as if he had something really valuable to say, something which, to follow Rorty's method, must be redescribed.

\section{The Philosopher and His Context}

By equating philosophy's creative drive to aesthetic and artistic creativity, Rorty wants us to read Nietzsche, Heidegger, and Wittgenstein as if they were completely detached from their humanity when it comes to write philosophy. Thus, in his essay "Cavell on Skepticism" (Rorty 1982), Rorty claims that Wittgenstein would have written pretty much the same books even if he hadn't had so much contact with the British philosophers for whom the problem of the external world was the main problem of philosophy back then:

Had Wittgenstein stayed in Central Europe, he would have met philosophy professors who worried more about the transcendental standpoint and less about skepticism. But he would probably have written pretty much the same books, and directed our attention to the same things. (Rorty 1982: 177)

11 Likewise, Rorty tells us a similar story of Heidegger, for whom he imagines a possible world where the German philosopher becomes more sensible to the Jewish Holocaust, and thus avoids the attraction of Nazism; nevertheless, in this possible world Heidegger writes almost the same books as he does in our actual world. ${ }^{3}$

For Rorty, the philosopher, just as it happens with the artist, uses imagination more than reason, feeling more than logic. That is why Rorty believes pragmatism to be closely linked with romanticism, since

These two movements are both reactions against the idea that there is something non-human out there with which human beings need to get in touch (Rorty 2007: 105).

This claim is closely linked to his claims against representationalism and metaphysical realism: namely, since the task of the philosopher is not to guide our knowledge to the true essence of things - for language is a tool which helps us cope with the environment rather than accurately penetrate it and represent it -, then, the remaining task for the philosopher is to enhance our imagination and direct our attention to unnoticed problems. For achieving such task the philosopher - just as the creative artist - invents his own vocabulary, since the current vocabulary of his community doesn't allow him to cope adequately with whatever he considers to be a problem. 

he did had he lived in different conditions (either place or time conditions) is a claim which lacks empirical or any sort of evidence; it is an speculative claim, for which, nevertheless, Rorty argues for. As opposed to this, I claim that all sensible evidence speaks against such claim; thus, when we study the history of ideas, one realizes that all ideas, even philosophical ones, belong to a certain historic and contingent paradigm and conceptual scheme. ${ }^{4}$ By claiming this I hope not to be understood as an all-out relativist for whom all truth-claims would merely depend on a discourse. The idea of Truth (absolute or relative) is something that must go by once we reject the Platonic picture of unity of reality. Instead, as pragmatists such as Rorty himself and Hilary Putnam have taught us, the pragmatist embraces the idea of diverse valid descriptions and conceptual relativity. According to this internal way to understanding philosophy, one has that what philosophers do is to

help you hold your time in thought. But we are not the people to come to if you want confirmation that the things you love with all your heart are central to the structure of the universe, or that your sense of moral responsibility is 'rational and objective' rather than 'just' a result of how you were brought up. (Rorty 1999: 20)

It would be contradictory for Rorty to hold that the philosopher can hold his time in thought and at the same time be outside of time himself. Such claim is not far from the metaphysical claim (held by philosophers with whom Rorty strongly disagreed, such as Bernard Williams and Thomas Nagel) that the philosopher should hold reality from a privileged view from nowhere. However, such is the image of the philosopher that one has after reading the above passages from Rorty.

This view of a detached philosopher tells us a great deal of Rorty's idea of the philosophical enterprise, namely, an ahistorical quest for certainty which deals with eternal problems that have little importance to mankind's lives. However, one must ask at this point, is this really Rorty's idea of philosophy?

When Rorty speaks of the philosopher as a detached individual, one has the idea that he would not be concerned with problems from its own time, but rather with ahistorical problems. Thus, the image that we have is of an individual completely detached from his history and situations when it comes to write philosophy. If this is so, then Rorty never fully took enough distance from the analytic philosopher's yearning of "keeping philosophy pure." According to this picture, the little and - only apparently insignificant contingencies in Heidegger's and Wittgenstein's lives (public and private) accounted for nothing in their philosophical creativity; for them life was something that happened outside of philosophy. ${ }^{5}$

\section{The Contingency of Philosophical Problems}

18 This way of understanding contingency and creativity goes far beyond the consequences which Rorty himself would have wanted to acknowledge. As any reader of Rorty knows, he didn't consider philosophical problems to have an eternal and never-changing nature. Instead, for him a philosophical problem was a way of speaking which had relevance up to a certain historical moment; after that moment such way of speaking became irrelevant. ${ }^{6}$ I don't think that he would have been happy with the image of a historically detached philosopher, and I really don't think that his Contingency, Irony, and Solidarity was written with such an image in mind.

European Journal of Pragmatism and American Philosophy, V-1 | 2013 
However, one cannot escape a feeling of contradiction in Rorty's writing when one compares what he said about the contingency of the philosopher's context when it comes to write philosophy with what he said about the contingency of philosophical problems. The feeling of contradiction is explicit because Rorty agrees with Dewey that

When it is acknowledged that under disguise of dealing with ultimate reality, philosophy has been occupied with the precious values embedded in social traditions, that it has sprung from a clash of social ends and from a conflict of inherited institutions with incompatible contemporary tendencies, it will be seen that the task of future philosophy is to clarify men's ideas as to the social and moral strifes of their own day. ${ }^{7}$ (Dewey 1982: 94)

Further, Rorty criticizes those contemporary philosophers such as Michael Ayers and Margaret Wilson who advocate an "absolutist stance" regarding philosophical problems, which amounts to

the conviction that the problems one addresses are inescapable once one begins to reflect - where 'philosophical reflection' denotes the activity of reconciling those persistent intuitions that survive changes in sociocultural circumstance. (Rorty 1998: 277)

How are we to put together the last two quotations with the former which claimed that

Had Wittgenstein stayed in Central Europe, he would have met philosophy professors who worried more about the transcendental standpoint and less about skepticism. But he would probably have written pretty much the same books, and directed our attention to the same things. (Rorty 1982:177)

As I said above, I would like to take Rorty in his own words and at the same time be fair to his conception of philosophy as a whole. That is why I insist that this last quotation is an unfortunate leftover of Rorty's analytic past.

One must remember that Rorty viewed philosophy as cultural politics, an enterprise which is set to modify and radically change the self-images of a given society. ${ }^{8}$ Thus, I want to preserve Rorty's idea of philosophy as a toolbox and at the same time uphold the metaphor of the philosopher as a child of his own time. ${ }^{9}$

The idea of a "detached" philosopher, occupied with eternal and impersonal problems, in other words, the idea of philosophical writing done sub specie aeternitatis, was the dominant idea regarding philosophical creativity until the second half of the 20th century. And in some respects such idea still presents itself as compelling, since many of the problems which troubled Plato still trouble sensible philosophers. However, this doesn't necessarily mean that philosophical problems are eternal, timeless, and inescapable. Rather, as Rorty understood it, philosophical problems are of such nature that allows for permanent reinterpretations and recontextualizations:

Dewey agreed with Hegel that philosophers were never going to be able to see things under the aspect of eternity; they should instead try to contribute to humanity's ongoing conversation about what to do with itself. (Rorty 2007: ix)

The importance of philosophical problems is that they help us keeping an ongoing interesting conversation, a conversation that still, to our own day, tells us something about our lives. Therefore, it is a mistake to reinterpret and recontextaulize the problems of philosophy ahistorically, without an appeal to their context. The idea of a "pure" philosophical problem, clean from the contingencies of its day and time, reminds us of the idea of the thing in itself, of something which remains untouched by human perspective. 
Rorty's historicist perspective claims that what the philosopher (and the historian of philosophy, for that matter) does is to reinterpret and translate such topics and language to the effect that they become relevant in his conversation. That is what Rorty means when he says that the philosopher cannot expect to produce writing which is not itself recontextualizable in many ways. That is precisely the appeal Rorty finds in philosophy: the possibilities it offers for permanent recontextualization and interpretation:

The most that an original figure can hope to do is to recontextualize his or her predecessors. He or she cannot aspire to produce works that are themselves uncontextualizable, any more than a commentator like myself can aspire to find the one "right" context into which to fit those works. (Rorty 1991: 2)

Given such appeal to interpretation through generations of philosophers, it is necessary, in order to keep the dialogue flowing, to appeal to the context in which a certain philosophical problem develops; therefore, there seems to be no possibility of recontextualization without an appeal to context. When approaching a philosophical problem, the philosopher, as well as the historian of philosophy, needs to enquiry as to how far the beliefs of previous philosophers who dealt with that problem permeate the problem itself. In other words, what is to be done is an exercise similar to that of Dewey's in The Quest for Certainty, where the philosopher approaches humanity's philosophical journey from within the social and cultural history in which it has developed.

\section{The Entanglement Between the Public and the Private}

8 With what has been said above I hope to have clarified some points about Rorty's claim that philosophical creativity arises in the void. Now I shall examine Rorty's ironic claim that the public and the private spheres are not to be consequently united.

As was remarked above, Rorty considered futile the Platonic drive to make a comprehensive unit out of the public and private spheres. Such yearning, he tells us, ends up in metaphysical antinomies which do not reflect adequately people's lives and do not help in coping with life's most important problems:

There is no way to bring self-creation together with justice at the level of theory. The vocabulary of self-creation is necessarily private, unshared, unsuited to argument. The vocabulary of justice is necessarily public and shared, a medium for argumentative exchange... The one tells us that we need not speak only the language of the tribe, that we may find our own words, that we may have a responsibility to ourselves to find it. The other tells us that that responsibility is not the only one we have. Both are right, but there is no way to make both speak a single language. (Rorty 1989: xiv)

The ironist - who, according to Rorty, is someone who doubts final vocabularies and its own vocabulary - finds inconsistencies in private and public discourse and cannot find a coherent and nonmetaphysical way to make them coincide; for him, "searches for a final vocabulary are not destined to converge" (Rorty 1989: 76).

After reading these passages, and after considering what was said above about the detached ironist philosopher, one might retain the impression that Rorty considered philosophers such as Nietzsche, Heidegger, and Wittgenstein as expressing their philosophical thoughts from a solipsistic stance, using a private language. However, one must ask again: is this really a consequence Rorty was willing to admit? Again, as was remarked above, and as any reader of Rorty knows, this is of course not a consequence 
which he would have upheld, since he strongly promoted the idea of philosophy as cultural politics. But then, why the insistence on private vocabularies and on the separation between public and private spheres? This is an inconsistency in Rorty's philosophy which needs to be looked upon. In what follows I offer two approaches to bridge such inconsistency.

First, I propose that we pay attention to Rorty's definition of the ironist. For hi m, the ironist is someone who fulfills three conditions:

(1) She has radical and continuing doubts about the final vocabulary she currently uses, because she has been impressed by other vocabularies, vocabularies taken as final by people or books she has encountered; (2) she realizes that argument phrased in her present vocabulary can neither underwrite nor resolve these doubts; (3) in so far as she philosophizes about her situation, she does not think that her vocabulary is closer to reality than others, that is in touch with a power not herself. (Rorty 1989: 73)

Some critics, like John Horton, find it difficult to make sense of the ironist's worries, since she must use the vocabulary of "right" and "wrong," a vocabulary which, as Horton sees it, cannot be linked with Rorty's anti-foundationalism:

Once we dispense with there being something which answers to the description 'the right tribe,' 'the right language game,' and 'the right sort of human being,' what is there for the ironist to worry about? (Horton 2001: 21)

For Horton, dispensing with foundationalism necessarily means getting rid of terms such as "right" and "wrong," therefore, the ironist is not really worrying, but merely expressing a personal preference of having been born in a different tribe and playing a different language game. However, this move is unnecessary, since accepting Rorty's antifoundationalism doesn't necessarily imply falling into relativism. The ironist can still speak of "right" and "wrong," but only in a creative and innovative sense, a sense in which standard moral commitments are challenged. As a creative individual the philosopher can still retain such talk of being mistaken or not, since he speaks of new and - until now - unimag ined extensions for such words.

A second approach for making sense of Rorty's insistence on the philosopher's apparent private language and the separation between the public and private spheres, consists on shifting the attention towards the important role imagination played in Rorty's philosophy and account of creativity. For him, "imagination creates the games that reason proceeds to play... In this sense, imagination has a priority over reason" (Rorty 2007: 115). For Rorty imagination sets the bounds of thought, giving rise to language and concepts. However, Rorty insisted, one must not think of imagination

as a faculty that generates mental images but as the ability to change social practices by proposing advantageous new uses of marks and noises... On this view, expressions like 'gravity' and 'inalienable human rights' should not be thought of as names of entities whose nature remains mysterious, but as noises and marks, the use of which by various geniuses have given rise to bigger and better social practices. (Rorty 2007: 107-8)

The history of philosophy is, for Rorty, the history of original and appealing ideas developed by very imaginative intellectuals. In those intellectuals Rorty recognizes the imaginative and creative drive of the poet, who sees himself as writing a poem in answer to his predecessors:

Nietzsche thought that Plato's success in putting the term 'really real' into circulation was a great imaginative achievement. But the answer to a poem is still a 
better poem, and that is what Nietzsche thought of himself as writing. (Rorty 2007:

117)

discourse which Rorty attributes to the philosopher (at least to the most creative ones). For Rorty, the private language of the ironist doesn't have any kind of impact on the public discourse, since it springs from different sources and its terms are unshared and unsuited to argument. However, one cannot but disagree with such opinion after reading the last two passages, in which a relation between the public and the private are made explicit. The clarity of this is such, that Rorty himself acknowledges it a few lines later, where, after describing imagination as setting the bounds of thought and as the spring of social change through the original use of marks and noises, he points that such imagination is bounded by practicality and common intentionality:

To be imaginative, as opposed to being merely fantastical, one must both do something new and be lucky enough to have that novelty adopted by one's fellows incorporated into their ways of doing things. The distinction between fantasy and imagination is between novelties that do not get taken up and put to use by one's fellows and those that do. People whose novelties we cannot appropriate and utilize we call foolish, or perhaps insane. Those whose ideas strike us as useful we hail as geniuses. That is why people like Socrates and Nietzsche often seemed like lunatics to some of their contemporaries and like heroes to others. (Rorty 2007: 107)

the detached and solipsistic endeavor suggested by Rorty in his Contingency, Irony, and Solidarity. As opposed to the idea of a detached genius whose language is exclusively private, one finds in this last quote the entanglement between enlightened private individuals and their fellow human beings. This quote shows how individual imagination sets the path for public discourse, and that such imagination cannot be solipsistic and "fantastic" if it wishes to get any acknowledgement besides its own creator. Such creative geniuses, like Socrates and Newton, and Kant and Dewey, have produced appealing ideas which were bounded not by language or a conceptual scheme (since according to this view it is them who are coming up with concepts), but by their practicality.

\section{"The Trail of the Human Serpent..."}

It is pragmatically convenient to hold philosophy as a set of tools which helps us cope with different problems as they come to us in history. One cannot expect that, for example, Wittgenstein would be an appropriate answer to all of culture's and philosophy's problems,${ }^{11}$ just as Dewey is far from answering all of our philosophical yearnings. In philosophy, just as in any other areas of culture, we not only find pleasure in variety, but wisdom too. This idea of philosophy as a toolbox is not incompatible with William James' claim that "the trail of the human serpent is over all": Wittgenstein, Heidegger and Dewey all were nothing but human beings, all too contingent, fragile and erring human beings. It is according with the classical pragmatism of James and Dewey to acknowledge the philosopher's humanity and contingency, and it doesn't harm philosophy (at least the idea of philosophy which Dewey, Wittgenstein, and Rorty shared)

European Journal of Pragmatism and American Philosophy, V-1 | 2013 
- or makes it an "impure" discipline - to start recognizing the trail of the human serpent in the best of philosophical writing; after all, philosophy is a human science in which the author - as opposed to the exact sciences - cannot be detached from its creation. creativity in philosophical writing: if thought is limited and conditioned by a historical
framework then it is impossible to think outside of such framework. Nevertheless, my reconstruction of Rorty's approach to creativity doesn't go that far as claiming that all thought is determined by social conditions, denying thus the space for individual creativity. As was said above, the best philosophical thought is produced by individuals who see themselves as writing not just a poem, but a practical narrative which they expect to be adopted by their fellows. However, as Spinoza ${ }^{13}$ and (more than two centuries later) the classical pragmatists saw it, man is not as free as he wishes to be; our thoughts and actions do not happen in the void, but are causally entrenched with the conditions which surround them. For Spinoza, man's thoughts and actions are bounded and causally occasioned by nature; and by nature Spinoza understood not only God, but reality as a whole (which of course includes human society); that is why he rejected the Cartesian idea of an all capable free will. However, nature itself allows man enough power to free himself from causes external to him, thus giving him the possibility to free himself from natural servitude. This idea is not totally foreign to pragmatism, since pragmatists such as James, Dewey, and Rorty, also welcomed the idea of thought and action as strictly social enterprises thus acknowledging the importance of private creativity in the service of public understanding. Rorty himself acknowledges such limits of creativity and language by insisting on doing philosophy from a historical perspective. Thus, he quotes Lorenz Krüger approvingly when he criticized "the assumption that philosophy is characterized by a specific set of tasks which remain constant through history" (Krüger quoted in Rorty 1998: 278). Krüger and Rorty agreed on the importance of holism in science and philosophy, the importance of recognizing that "the discovery, as well as the justification of an advanced theory requires the predecessor theory, or rather the chain or net of predecessor theories" (Rorty 1998: 278). Thus, Rorty continues, "this historicity gives one reason to doubt that the history of philosophy can be written independently of cultural history" (Rorty 1998: 278). One cannot but agree with Rorty that, in the end, what philosophers do, at least those who are most remembered, is to change the subject of the conversation and the terms in which such conversation is carried. Rorty saw that very clearly, though he, as a child of his own time - namely, the analytic age - sometimes kept a certain respect for philosophy as a discipline untainted from social contingencies; thus, as I tried to claim, he was never able to fully acknowledge the overreaching trail of the human serpent. 


\section{BIBLIOGRAPHY}

AYER A.J. (1978), Part of My Life, Oxford, Owford University Press.

HORTON J., (2001), “Irony and Commitment: an irreconcilable dualism of Modernity," in M. Festenstein and S. Thompson (eds.), Richard Rorty: Critical Dialogues, London, Polity Press, 2001. RORTY R., (1982), Consequences of Pragmatism, Minneapolis, University of Minnesota Press. RORTY R. (1989), Contingency, Irony, and Solidarity, Cambridge, Cambridge University Press. RORTY R. (1991), Essays in Heidegger and Others, Philosophical Papers vol. 2, Cambridge, Cambridge University Press.

RORTY R. (1998), Truth and Progress, Philosophical Papers vol. 3, Cambridge, Cambridge University Press.

RORTY R. (1999), Philosophy and Social Hope, London, Penguin.

RORTY R. (2007), Philosophy as Cultural Politics, Philosophical Papers vol. 4, Cambridge, Cambridge University Press.

RORTY R. (2010), “Intellectual Autobiography,” in R. Auxier, and L. Hahn (eds.), The Philosophy of Richard Rorty, The Library of Living Philosophers, Chicago, Open Court, 2010.

RORTY R., SCHNEEWIND J. B., \& Q. SKINNER, (eds.), (1984) Philosophy in History, Cambridge, Cambridge University Press.

SHAPIN S. (2010), Never Pure: Historical Studies of Science as if It was Produced by People with Bodies, Situated in Time, Space, Culture, and Society, and Struggling for Credibility and Authority, Baltimore, Johns Hopkins University Press.

\section{NOTES}

1. See the Introduction to Contingency, Irony, and Solidarity, and "Trotsky and the Wild Orchids."

2. See the essays in his Essays on Heidegger and Others, Philosophical Papers vol. 2; and "Pragmatis $\mathrm{m}$ and Romanticism" in Philosophy as Cultural Politics, Philosophical Papers, vol. 4.

3. “On Heidegger's Nazism” (Rorty 1999: 190-97).

4. The case of Wittgenstein is particularly interesting, since his last writing, On Certainty, was cle arly inspired by his discussions with and the writings of G.E. Moore regarding the problem of ske pticism about the external world.

5. The idea that "life" is something totally independent and separated from philosophy was clearl y stated by A. J. Ayer when he remarked to Isaiah Berlin that "philosophy is linguistic analysis, th e rest is life." See A. J. Ayer's Part of My Life.

6. See "The Contingency of Philosophical Problems: Michael Ayers on Locke" in Rorty 1998.

7. This passage by John Dewey is quoted by Rorty in his 1998: 276.

8. See Rorty's preface to Philosophy as Cultural Politics.

9. I do not believe that Rorty was aware that by holding his main ironic thesis of Contingency, Irony, and Solidarity he would deny his other Hegelian thesis of the philosopher as a child of his ow n time. 
10. See particularly "Philosophy as science, metaphor, and as politics" in Rorty 1991; and "Pragm atism and Romanticism" in Rorty 2007.

11. Unfortunately, a quick bibliographical search will show that many commentators of Wittgens tein hope to find in him a correct answer to all of culture's problems, something similar as Aristo tle was for the medieval mind.

12. Nevertheless, the writings of Steven Shapin have promoted a fruitful and rewarding sociologi cal approach to the history of philosophic and scientific ideas. See Shapin 2010.

13. By linking Spinoza's idea of freedom with classical pragmatism I expect to be doing - rather than making a historical mistake - what Rorty saw himself as doing throughout his philosophical lif e, namely, "trying to coax pairs of philosophers into each other's arms- sometimes to their discomfort and annoyance." "Rorty's Intellectual Autobiography," in Auxier \& Hahn 2010.

\section{ABSTRACTS}

In this essay I propose a criticism of Richard Rorty's dualism between the public and the private. According to Rorty's ironic utopia, the intellectual should not try to fuse public and private drives, since both spring from different sources and are qualitatively incompatible. Thus, Rorty's utopia consists in a radical irreconcilability between private intellectuals who create their own language and the general public for which such language has little to no impact. In this essay, however, I argue that Rorty's ironic proposal is not consistent since: 1) Rorty himself acknowledges that the vocabulary and imagination of private intellectuals, such as Socrates and Galileo, eventually - if it is appealing enough - becomes the canon; and 2) because Rorty's conception of philosophy, which he shares with the classical pragmatists, does not allow the idea of a philosophical problem as not making a difference in practice, which is the case with the problems with which is concerned the creative philosopher of Rorty's utopia. As opposed to such detached idea of philosophical creativity, I argue that, as the classical pragmatists claimed, all philosophical thought, in order to account as a practical difference, is relational, and not, as Rorty claimed, romantically solipsistic.

\section{AUTHOR}

\section{JAVIER TORO}

Universitat de Valencia

spinozayer[at]yahoo.es 